Birds

of the Northwestern

National Parks 
Number Forty-five,

The Corrie Herring Hooks Series 


\title{
BIRDS
}

\section{of the NORTHWESTERN NATIONAL PARKS}

\author{
A Birder's Perspective
}

Olympic National Park, Washington

North Cascades National Park, Washington

Mount Rainier National Park, Washington

Crater Lake National Park, Oregon

Oregon Caves National Monument, Oregon

Lava Beds National Monument, California

Lassen Volcanic National Park, California

By Roland H. Wauer

Drawings by Mimi Hoppe Wolf

University of Texas Press, Austin

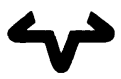


Copyright $\odot 2000$ by Roland $\mathrm{H}$. Wauer

All rights reserved

Printed in the United States of America

First edition, 2000

Requests for permission to reproduce material from this work should be sent to Permissions, University of Texas Press, P. O. Box 7819, Austin, TX 78713-7819.

The paper used in this book meets the minimum requirements of ANSI/NISO Z39.48-1992 (RI997) (Permanence of Paper).

Library of Congress Cataloging-in-Publication Data Wauer, Roland $\mathrm{H}$.

Birds of the northwestern national parks : a birder's perspective / by Roland $\mathrm{H}$. Wauer ; drawings by Mimi Hoppe Wolf. — ist ed.

p. cm. - (Corrie Herring Hooks series; no. 45)

Includes bibliographical references (p. ) and index.

ISBN: 978-0-292-79133-6

1. Birds-Pacific States. 2. Bird watching-Pacific StatesGuidebooks. 3. National parks and reserves-Pacific StatesGuidebooks. 4. Pacific States-Guidebooks. I. Title.

II. Series.

QL683.P37 W38 2000

$598^{\prime} .07^{\prime} 234795-\mathrm{dc2} 1$

99-055373 